\title{
Spenserian "entry codes" to indirect satire
}

In his own satirical poetry, Edmund Spenser criticized indirectly, requiring readers to interpret clues carefully to access satirical meanings. For some readers, such as Joseph Hall and William Bedell, Spenser's reputation as a decorous, conservative poet seemed to obscure awareness of him as also demonstrating an interest in or affinity for satirical writing, as discussed in Chapter 3. This chapter offers a corrective in the form of "case studies" of three poets who were quite sensitively attuned to the potential for satirical readings or uses of Spenserian intertexts. Analyzing Thomas Nashe's Choise of Valentines with reference to Spenser's "March" eclogue from The Shepheardes Calender and Tailboys Dymoke's Caltha Poetarum alongside Spenser's Muiopotmos gives a sense of the code of indirect satire as a flexible vocabulary of subterfuge and innuendo. In Nashe's, Dymoke's, and (in the chapter's "coda") Shakespeare's responses to and reworkings of Spenserian images and narratives, we see the overwhelming significance of Spenser in the literary field of the 1590s.

\section{Hunting love and catching Cupid in Spenser's "March" and Nashe's Choise of Valentines}

In A Choise of Valentines, Thomas Nashe playfully uses Spenser's "March" eclogue from The Shepheardes Calender as an intertext for his own poem. Nashe imitates the methods of Spenserian satire to create a bawdy poem that mocks the ideas about love put forth by Spenser and Spenser's own source-texts while nevertheless endorsing the dichotomies of city and country that are staples of pastoral satire. The poem is outrageous and funny, especially if we consider the possibility that Nashe satirizes both Frances Walsingham and Queen Elizabeth with his bawdry, but, in the contrast between country and city, Nashe implicitly accepts pastoral's valorization of the moral superiority of the country. Reminiscent of Colin 
Clout in the "neighbor towne" ("Januarye," line 50), Nashe's Tomalin learns to hate the distortion that the urban space enforces on pastoral love.

Until recently, critics have not been kind to Thomas Nashe's bawdy poem A Choise of Valentines (written 1592; published 1899). ${ }^{1}$ The poem has disappointed those hoping to glean some juicy biographical tidbits, with G.R. Hibbard complaining that "Nashe's attitude to sexual matters is too normal and healthy to be anything but dull"; Charles Nicholl determining only that "the man who wrote it was certainly no virgin"; and Stephen Hilliard discovering the unshocking fact that "the poem, like much pornography, mechanizes sex and demeans women" (Hibbard, Nashe, 57; Nicholl, Cup of News, 92; Hilliard, Singularity, 199, respectively). More fruitfully, scholars have identified numerous classical, Continental, and English sources and intertexts for the poem. Although Hibbard dismisses the poem as "largely derivative" (57), the learnedness and creativity required to combine and rework such a variety of inspirations as Ovid, Maximianus, Chaucer, Aretino, and Marlowe suggest the need for a revaluation of the poem's literary merit. ${ }^{2}$ I will add here to the list of Nashe's influences by arguing that Spenser's "March" eclogue from The Shepheardes Calender serves as an important intertext for the poem. Reading Nashe's poem as a satire, in conversation with "March" and its sources, allows us to understand The Choise of Valentines as both a serious use of satire to explore ideas about love and a mean-spirited satire probably targeted at Frances Walsingham, widow of Sir Philip Sidney and, at the time of the poem's composition, wife to Robert Devereux, Second Earl of Essex.

In the 316-line poem, the narrator goes to his "ladies shrine" on Valentine's Day but finds that "Iustice Dudgein-haft" has frightened her from her usual place, and she has taken refuge in a brothel, where he goes to seek her (Nashe, Choise, lines 17, 21). The madam shows him some "prettie Trulls" (line 50), but he asks instead for his sweetheart by name: "Fetch gentle mistris Francis forth to me" (line 56). She appears, the madam leaves them, and foreplay ensues, but the narrator's penis fails

1 See Nicholl (Cup of News, 90) for evidence for 1592 as the likely year of composition.

2 M.L. Stapleton has extensively analyzed the classical sources for the poem, with special attention to Ovid in "Nashe and the poetics of obscenity" and to Maximianus in "A new source." For discussions of Chaucer as a source for the poem, see, for example, Hibbard, Nashe, 58; Evans, "Nashe's 'Choise"; Clark, "Writing sexual fantasy." David O. Frantz argues for Aretino as inspiration more than source ("Leud Priapians"). Nicholl argues for Marlowe's translation of Ovid as "not so much the model as the precedent for Nashe's Dildo" (Cup of News, 94). 
to become erect. The sweetheart gently suggests, "Com, lett me rubb and chafe it with my hand. / Perhaps the sillie worme is labour'd sore" (lines 132-33). She does so, and a bout of intercourse follows; although it lasts for fifty-six lines before the narrator reaches a poetic (and physical) climax in which he likens his emission to Jove's "golden shoure" (line 194), the time is insufficient for his sweetheart, and she begs for more: "Staie but an houre; an houre is not so much, / But half an houre; if that thy haste be such: / Naie but a quarter; I will aske no more" (lines 215-17). The narrator's penis obdurately refuses to comply with the sweetheart's wishes, at which point she swears off men, gets out her dildo, and delivers a paean to it as she finishes the job left undone by the narrator. The poem ends with the narrator delivering a wrathful diatribe against dildos before paying the madam and slinking away from the brothel. The poem is indeed, as Gabriel Harvey sniffed, a "pack of bawdry" (Harvey, Pierces Supererogation, 45), but all this is not without meaning.

The dedicatory sonnet "To the right Honorable the lord S" (generally though not universally believed to refer to Ferdinando Stanley, Lord Strange $)^{3}$ provides the first hint of Spenser's importance to an understanding of the poem. Hibbard points out parallels between this poem and Spenser's "To the right Honourable the Earle of Oxenforde," one of the dedicatory sonnets to The Faerie Queene, while Stapleton notes a generalized Spenserianism in the diction, including "the Spenserian trademark 'Ne,' a line of mellifluous monosyllables, filler adjectives ... that do very little to modify the nouns they precede, and the distorted word-order to fit the rhyme: all can be found in practically any passage of Spenser" (Hibbard, Nashe, 56; Stapleton, "Nashe," 38). The satirical import of a dedicatory sonnet to Lord Strange that alludes to Spenser becomes clearer read alongside Nashe's nearly contemporary sonnet to Spenser in reference to Lord Strange (that is, "Amyntas") in Pierce Penilesse His Svpplication to the Diuell (1592). Andrew Zurcher provides a careful analysis of Nashe's satire of Spenser in Pierce Penilesse: mockery of the disorderly publication of the dedicatory sonnets-in the back, with variable numbers of dedicatees, presumably because Spenser made the mistake of forgetting Lord Burghley in the first round of dedicationsserves as the general backdrop for specific criticism of Spenser for failing to honor Lord Strange (Zurcher, "Getting it back to front"). Either explicitly or implicitly, both sonnets pit Lord Strange against Spenser, and Nashe sides with Lord Strange.

3 See McKerrow, "Commentary," IV.150-51 and V.141n1, for his analysis of the evidence in favor of Lord Strange as the dedicatee of Choise. 
When the poem itself begins, we sense the influence of both Chaucer and Spenser:

It was the merie moneth of Februarie

When yong-men in their iollie roguerie

Rose earelie in the morne fore breake of daie

To seeke them valentines so trimme and gaie.

(Nashe, Choise, lines 1-4)

The situation of choosing a sweetheart on St. Valentine's Day parallels Chaucer's Parliament of Fowls, but the Spenserianism of the dedicatory sonnet primes the reader to read the Chaucerianism of the opening lines as "Chaucer's manner as refracted through the medium of Spenser" (Hibbard, Nashe, 58). Further, these lines echo the opening of the interpolated tale that Thomalin tells his friend Willye in the "March" eclogue of The Shepheardes Calender:

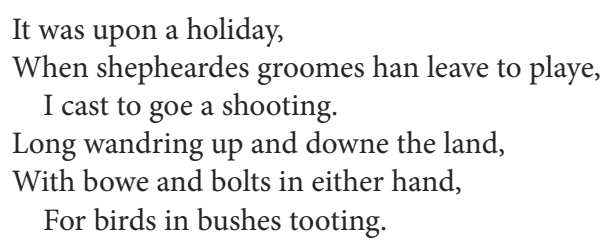

(lines 61-66)

The identification of "March" as an intertext becomes stronger when we learn that the narrator of Nashe's poem is named Tomalin. Katherine Duncan-Jones connects the name of Nashe's speaker to Tam Lin, the elfin hero of early modern ballads, but I believe a Spenserian derivation is more plausible (Duncan-Jones, "City limits"). ${ }^{4} \mathrm{~A}$ Thomalin appears as a speaker in "March" and "Julye" of Shepheardes Calender, and we see the name and its variant Tomalin signaling pastoralism (and Spenserianism) in several poems published afterward: for example, a Thomalin appears in William Browne's The Shepheards Pipe (1614), and Phineas Fletcher includes Thomalins in The Purple Isle (1633) and the Piscatory Eclogues (composed 1606-15; published 1633). The spelling Tomalin also appears in pastoral: Andrew Marvell creates a conversation among Hobbinol, Phillis, and Tomalin in his "Second Song" on the marriage of Lord Fauconberg and the Lady Mary Cromwell (written 1657; published 1681), and the anonymous poet of $A$ pastoral occasion'd by the arrival of His Royal

4 Note that Richard Lynn argues that Spenser himself uses the name Thomalin to allude to Tam Lin in order to intensify a topical satirical take on the marriage of the Earl of Leicester and Lettice Knollys (“Ewe/who?"). 
Highness Prince George of Denmark (1683) names his speakers Tomalin, Willie, and Hobbinol. The name Tomalin thus indicates a pastoral setting, and Nashe here signals pastoralism in order to satirize or critique it, as Jonathan Crewe suggests when he argues that the poem allegorizes the loss of "an ideal pastoral order" in which a shift from country to city emerges as "a moment of profound dislocation and loss. The city emerges not as positive material or social entity to be written 'about', but always paradoxically as a place of deficiency and negation" (Crewe, Unredeemed Rhetoric, 48, 53).

Nashe uses the name Tomalin and the opening of the poem to call the reader's attention to "March" as an intertext for A Choise of Valentines; having done this, he then repeatedly alludes to "March" and to Spenser's source-texts in one of Bion's idylls ("Fragment XIII") and Ronsard's adaptation "Lamour oyseau." The plots in Bion/Ronsard, Spenser, and Nashe all include the following elements: a boy or young man goes hunting, finds love (or Love), and learns of its dangers. Bion's hunting boy finds Cupid in the form of a beautiful bird in a box-tree; he fails to trap the bird and tells the story to an old man, who tells him he is lucky not to have caught the dangerous bird of prey (Ronsard changes the old man to an old woman). Spenser's Thomalin finds Cupid "within an Yvie todde" ("a thicke bushe," E.K. informs us); he is a "naked swayne / With spotted winges like Peacocks trayne" (lines 67, 79-80). Thomalin shoots arrows and throws stones but fails to catch the winged boy. Cupid gets his revenge by shooting Thomalin with one of his arrows; now the wound "ranckleth more and more, / And inwardly it festreth sore," and Thomalin doesn't know "how to cease it" (lines 100-2). Nashe's Tomalin, along with the other young men, goes hunting "To seeke ... valentines" (line 4). "Good Iustice Dudgein-haft" has scared his sweetheart Frances away from her usual spot, and she has sought refuge in a brothel. Tomalin apparently finds love (small $l$ ) in the first half of his sexual encounter and Love

5 Although Spenser is generally understood to owe more to Ronsard than Bion as source for Thomalin's story in "March," he knew both versions of the story. Leo Spitzer notes a plot detail present in Bion but not Ronsard that suggests that Spenser drew upon the Greek poem ("Spenser," 504n5). Spenser certainly knew the Ronsard version, as indicated by his use of peacock imagery for Cupid, which Ronsard used in editions of this poem before 1560: "Son plumage luisoit plus beau / Que n’est du Paon la queüe étrange" (quoted in Harrison, "Spenser," 141). See Prescott (French Poets, 109, 263n50-52) for a summary of scholarship on Spenser's uses of sources for Thomalin's story in "March." Spenser himself obviously wanted to highlight his ancient Greek source in Bion more so than Ronsard, given that E.K. notes, incorrectly referring to Theocritus instead of Bion, "THIS Æglogue seemeth somewhat to resemble that same of Theocritus, wherein the boy likewise telling the old man, that he had shot at a winged boy in a tree, was by hym warned, to beware of mischiefe to come" (62). 
(capital $l$ ) in his neo-Platonic effusions during intercourse, but his failure to satisfy Frances, and the consequent shame at being supplanted by the dildo, teach him of love's dangers. He ends the poem "quitte discourag'd ... / Since all my store seemes to hir, penurie" (lines 299-300). When Nashe refers to the earlier sources, he uses the allusion to provide a contrast or implied critique of the idealism and innocence of the earlier texts.

Where love/Love is found differs importantly but not randomly in these poems. Spenser alters his sources' box tree into an "Yvie todde." Leo Spitzer hypothesizes that Spenser's innovation stems from a "desire not only to acclimate our episode in England, but also to enforce the 'dormant' aspect of Love ... the statue of Cupid covered with ivy represents then the minimum of Love's effectual force" (Spitzer, "Spenser," 500). I would argue instead that Spenser makes the change in order to complicate the bird imagery of his Cupid. Spenser compares his Cupid explicitly to a peacock, with references to his "winges like Peacocks trayne" and "winges of purple and blewe" (lines 80, 33). And yet, in English bird symbolism, the ivy tod belongs to the owl. The Oxford English Dictionary provides three sixteenth- and seventeenth-century examples connecting owls with ivy tods, ${ }^{6}$ but Robert William Dent found many more in a study examining only dramatic writing (Dent, Proverbial Language, II.567). Certainly, for Spenser's readers, "like an owl in an ivy-bush" (or "ivy-tod") was common enough to be proverbial. Both of Spenser's sources place Cupid in a box tree (Bion: "pyxoio," from pyxos, "Fragment XIII," line 3; Ronsard: "Buys," "Lamour oyseau," line 22), so the shift to ivy demands attention. The strong connection between owls and ivy tods suggests Spenser's aim to connect Cupid with the owl. Spenser's bird imagery thus becomes much more specific, and complex, than Bion's simple "mega ... orneon" ("big bird") or even Ronsard's reference in early editions to a "paon," or peacock. The peacock, which Spenser connects to both Juno and Cupid in Muiopotmos through comparison with Clarion's wings, symbolizes the appealing aspect of love, but Spenser innovates on his sources by also providing a specific bird image for the dangerous side of love. In Bion, the old man says of the bird, "kakon esti to thērion" ("The creature is evil"), and in Ronsard, the old woman describes it as "Loiseau de mauvaise rencontre" ("the bird of bad meeting"). By locating Cupid in an ivy tod, Spenser alludes to the owl, thus importing into the poem

6 The Oxford English Dictionary Online (s.v., "ivy-tod, n.") provides the following examples: "as owles out of an yuye todde" from T. Becon's Relikes of Rome (1553); "Your Ladiship, Dame Owle, Did call me to your Todd" from W. Warner's Albions England (1592); and "Men of Britain, Like boading Owls, creep into tods of Ivie" from J. Fletcher's Bonduca (1625). 
the ominous symbolism associated with this bird. In both occurrences of the word "owl" in Shepheardes Calender ("June," line 24; "December," line 72), Spenser uses the adjective "ghastly" to modify the noun, suggesting the ill-omened nature of the owl. Spenser makes another change to his sources in changing the lime twigs and snares of Bion and Ronsard to arrows and rocks, which Thomalin uses, and especially the "fowling net" in which Willye's father caught Cupid. The image of the net connects the entrapment of Cupid with the cliché of the sonneteer caught in the golden net of his lady's hair, as for example in sonnet 12 of Sidney's Astrophil and Stella, where Astrophil calls Stella's "locks" Cupid's "day-nets" (line 2) and in Amoretti 37, where Spenser himself describes the beloved's hair as a "net of gold," a "golden snare," and a "guilefull net" (Spenser, "Sonnet XXXVII," lines 2, 6, 10).

I have taken time to detail these patterns of imagery and symbolism in Spenser and in his sources, Bion and Ronsard, both to highlight the playful inventiveness of Nashe's allusions to these sources and to support my argument that Nashe's alterations create a consistent satirical message mocking naïvete in love. Bion's box tree as perch for Cupid becomes Nashe's "Good Iustice Dudgein-haft"; Spenser's bird imagery for Cupid becomes in Nashe's poem avian metaphors for the dildo; and Nashe transforms the "fowling net" used to catch Cupid in Spenser into the "duskie nett of wyres" of Frances's pubic hair.

"Good Iustice Dudgein-haft," who frightens Frances so that she seeks refuge in a brothel, has a remarkable name, one that indicates the stern rigor of the magistracy:

For she was shifted to an upper-ground.

Good Iustice Dudgein-haft, and crab-tree face

With bills and staues had scar'd hir from the place;

And now she was compell'd for Sanctuarie

To flye unto an house of venerie.

(lines 20-24)

Critics have generally read Frances's move as a shift from the country to the city, based on J.B. Steane's reading of "upper-ground" as referring to Upper Ground Street, "a street of low repute in Southwark," in contrast to the "toune-greene," "fields," "village," and "Contrie" mentioned as part of the setting before the shift to the brothel (lines 6, 8, 9, 13) (Steane, "Introduction and notes," 459n11). In this case, Iustice Dudgein-haft lives in the country, but he seems to represent the type of judicial official who would enforce the suppression of brothels in London that occurred after 1570 (Moulton, Before Pornography, 171 and 242n35). Whether in the country 
or the city, Iustice Dudgein-haft represents an allegorized character inimical to love, and this provides the key to understanding how his name fits within the complex system of plant and bird imagery developed in Spenser and his sources' treatment of the basic story, because "dudgeon" refers to the root of boxwood, the same box tree in which the boy finds Cupid in Bion and Ronsard (s.v. "dudgeon, n. "). ${ }^{7}$ Through this odd name, Nashe alludes to the location of Cupid in Spenser's sources in a way that underscores the implications for love of the shift from the pastoral to the urban setting. What was once natural is transformed through human artisanship into something violent and oppressive, and the social and judicial pressure from Iustice Dudgein-haft transforms Frances from a valentine into a whore.

Similarly to this playful alteration of the tree imagery, Nashe also builds on Spenser's innovation of the fowling net to convey his critique of naïvely idealizing ideas about love. Whereas Spenser's fowling net to catch Cupid calls to mind the sonnet topos likening a woman's hair to a net to catch men, Nashe creates a more bawdy and unappealing twist to this image by shifting attention from the hair on a woman's head to her pubic hair. Following an idealizing description of Frances's belly, Tomalin descends:

At whose decline a fountaine dwelleth still,

That hath his mouth beset with uglie bryers

Resembling much a duskie nett of wyres.

(lines 112-14)

In sonnetry, the "nets" or "wires" of women's hair must be golden to be appealing, leading to Shakespeare's satire on sonnet clichés: "If hairs be wires, black wires grow on her head" (Shakespeare, "Sonnet 130," line 4). Ian Moulton compares Frances's "duskie nett" to Acrasia's veil in The Faerie Queene, to the Palmer's "subtile net" that captures her, and to Vulcan's net that captured Venus and Mars (Moulton, Before Pornography, 174). Although Moulton focuses strictly on net imagery with negative connotations, the poem's Spenserian intertextuality means we need to consider the ways that this ugly image also references, in order to satirize, the more appealing images of a fowling net to catch Cupid and women's golden hair as a net to trap men.

Finally, Nashe uses two of Spenser's three bird images in "March" to connect the dildo to Cupid, which, given the low esteem in which the

7 In addition to the examples provided in the $O E D$, see also Wilkins, who defines "Dudgeon" as "Root of Box" and "dudgeon-dagger" as "Short Sword whose handle is of the root of Box" (Alphabetical Dictionary, Eee4v). 
narrator holds the dildo, serves as a clear critique of Cupid and the ideologies of love associated with him. As already noted, Spenser makes the bird imagery connected with Cupid in "March" much more specific than that found in Bion or Ronsard, with explicit reference to the peacock and the crow and the suggestion of the owl by placing Cupid in the ivy tod. Nashe alludes to this bird imagery and also develops his own, still with reference to "March." First, the bird imagery used to refer to Frances herself bifurcates the sense of hunting for love found in "March." Whereas Spenser's Thomalin "cast[s] to goe a shooting / ... / For birds in bushes tooting" (lines 63, 66) and finds only Cupid, not an actual woman, Nashe's Tomalin seeks an avianified woman. Tomalin, along with the other men, rises early in the morning "To seeke ... valentines" (line 4), but Tomalin of course cannot find Frances, because she "was compell'd ... / To flye unto an house of venerie" (lines 23-24; here, the pun on "venery," which can also refer to hunting, contributes as well to the imagery of hunting real birds). ${ }^{8}$ At the brothel, he speaks to the madam, who "us'd to take yong wenches for to tame" (line 30). He attempts to hire Frances, and the madam tells him it will cost him, for "he that will eate quaile's must lauish crounes" (line 63; see Williams, "Quail," for contemporary uses of "quail" as slang for a prostitute, including this one). The quest for love, allegorized in Spenser and his sources as a hunt for Cupid, becomes closer to an actual hunt here, given that the "quail" is a human character, not an anthropomorphized and deified abstraction. The quail has been flushed, and she alights after her flight in a place that, in "taming" her, obliges her to be caught by anyone who will pay. She thus becomes, briefly, a perfect fantasy: a pure sweetheart, but one required to have sex with Tomalin because she took sanctuary in a brothel.

Any sense of Frances as a victim of the hunt for love dissipates, however, when she begins not only to assert herself sexually but to berate Tomalin for his unimpressive performance. We can assume that Nashe assumes a male reader, and that this male sixteenth-century reader would feel for Tomalin when Frances apostrophizes his penis thus:

Adiew faint-hearted instrument of lust,

That falselie hast betrayde our equale trust.

Hence-forth no more will I implore thine ayde,

Or thee, or men of cowardize upbrayde.

My little dilldo shall suplye their kinde.

(lines 235-39)

8 I am indebted to Yulia Ryzhik for this observation. 
By this point she has metamorphosed from hunted quail to brazen strumpet, and here Nashe initiates the use of bird imagery for the dildo itself, thus linking it with Cupid in Spenser's "March" while giving it pride of place: Frances tells Tomalin that the dildo "playes at peacock twixt my leggs right blythe" (line 243). In response to Frances's paean to the dildo, Tomalin execrates it at some length, calling it among many other things "blinde mischapen owle" (line 288). Frances in her enthusiasm for the dildo uses the image that Spenser used for the beautiful aspect of Cupid, and Tomalin in his anger and shame at being supplanted by it uses one of the bird images that Spenser used to convey a sense of the danger of the bird that the innocent boy finds. The bird imagery links the dildo to Cupid, but, according to Tomalin, the dildo is more powerful than both Priapus and Cupid. Priapus's "triumph now must falle" unless he "thrust this weakeling to the walle" (lines 247-48). As for Cupid, the dildo "wayte's on Courtlie Nimphs, that be so coye, / And bids them skorne the blynd-alluring boye" (lines 255-56). The inanimate object thus becomes not only personified but almost deified by comparison with these other gods of sex and love.

Comparing Ronsard's-and, later, Spenser's - version of the story with that of Bion, Don Cameron Allen concludes, "It must be confessed, I think, that when we reach the end of Ronsard's poem our veins are less warmed and our sensibilities less charmed than they were when we had only Bion in our emotional history. Love has become more distasteful. It is associated with birds of ill omen, with witchcraft, with wounds, with bitterness" (Allen, "Three poems," 184). It must also be confessed that when we reach the end of Nashe's poem love has become even more distasteful, associated with prostitution, impotence, premature ejaculation, insatiable female desire, and especially the dildo.

Both love and Love take a beating in Nashe's satirical treatment of Spenserian idealizations of love and women, but "March"-with its sly allusion to Lettice Knollys, whose secret marriage to the Earl of Leicester led to their banishment from court upon its discovery in 1579-also provides us with a clue to another of Nashe's satiric intentions. If the name Tomalin in The Choise of Valentines calls attention to Spenser's "March" as an intertext, then the name Lettice in "March" ("And learne with Lettice to wexe light," line 20) cues us to consider the possibility that the name Frances in A Choise of Valentines refers to an actual person. Based on internal evidence of Frances's wealth and high status in the poem and external evidence of what personal satirical targets might be most amusing to Lord Strange, the dedicatee of the poem and Nashe's 
patron at this time, ${ }^{9}$ I speculate that the name refers to Frances Walsingham, who was in 1592 the wife of Robert Devereux, Second Earl of Essex, having been widowed in 1586 by the death of her first husband, Sir Philip Sidney.

In the poem, Frances dresses neither like a country lass nor like a prostitute, but like a great lady. The madam, in telling Tomalin of Frances's high price, notes:

And mistris Francis in hir veluet goune's,

And ruffs, and periwigs as fresh as Maye

Can not be kept with half a croune a daye.

(lines 64-66)

When Frances enters the room, Tomalin watches her:

Sweeping she coms, as she would brush the ground,

Hir ratling silke's my sences doe confound.

(lines 77-78)

The Countess of Essex would surely be the most famous Frances at the time to wear "ratling silke's," and the connections between Frances, Countess of Essex, and Lettice Knollys, alluded to in Spenser's "March," strengthen the sense that Nashe had Spenser's bold reference in mind in naming his valentine-whore Frances.

Whether one agrees with Charles Mounts that Spenser's potentially inflammatory reference to "Lettice" was an accidental holdover from an earlier manuscript or with Richard Rambuss that alluding to the Earl of Leicester's marriage serves as a means of advertising his discretion by showing he "knows-and 'keeps'-the secret" (Mounts, "Spenser," 199-200; Rambuss, Spenser's Secret, 24), we can expect that savvy sixteenth-century readers would doubt E.K.'s obfuscatory note glossing "Lettice" as "the name of some country lasse" (63n20). Richard Lynn, in a very detailed reading of the poem, argues that "March" is a much more specific-and mean-spirited-satire than has previously been thought, criticizing Lettice Knollys for marrying the Earl of Leicester, thus damaging his standing with the Queen. Identification of the "Lettice" of "March" with the Countess of Leicester would be even more likely because of the near contemporaneity of the scandal: The Shepheardes Calender was entered in the Stationers' Register in December 1579, just two months after the Queen learned, in early October, of the Earl of Leicester's secret

9 See Nicholl (Cup of News, 87-90) for details about the patronage relationship between Nashe and Lord Strange. 
marriage to Lettice Knollys (MacCaffrey, Queen Elizabeth, 261-62).

Several details connect Lettice Knollys and Frances Walsingham, both of whom secretly married favorites of the Queen, leading to public scandal. Before her marriage to the Earl of Leicester, Knollys was the widow of Walter Devereux, First Earl of Essex, to whom she bore Robert, Second Earl of Essex; she was thus mother-in-law to Frances Walsingham. Additionally, Knollys's daughter, Penelope Devereux, was Sidney's Stella before his marriage to Walsingham, which may have been, but probably was not, known to Thomas Nashe in 1592. Walter Friedrich notes that the identification of Stella as Penelope Devereux Rich was not widespread until 1598, when the folio edition of Sidney's works brought the sequence's Sonnet 37 into print for the first time, and notes that before-and even after-that date, writers, including of course Spenser in Astrophel, frequently misidentify Frances Walsingham as Stella (Friedrich, "Stella"). In his introductory note to Thomas Newman's unauthorized 1591 edition of Sidney's Astrophil and Stella, Nashe says nothing about the identity of Stella (Nashe, "Somewhat to read," A3r-A4v). Given the Countess of Pembroke's anger over the piracy of her dead brother's works, leading to the impounding of the edition and the removal of Nashe from involvement in the subsequent edition (Nicholl, Cup of News, 83), we can assume that Nashe did not receive private communications from the family about the true identity of Stella before penning The Choise of Valentines the following year.

Assuming that Nashe mistakenly believes Frances Walsingham to be Stella helps to explain the imagery of suns, stars, and planets in Choise's sex scene. But whereas Sidney's Stella was a star-woman, and whereas Nashe describes Sidney himself as "Englands Sunne" ("Somewhat to read," A3v), in Choise Frances is the sun, and Tomalin the star:

On him hir eyes continualy were fixt,

With hir eye-beames his melting looke's were mixt,

Which lyke the Sunne, that twixt tuo glasses plaies

From one to thother cast's rebounding rayes.

He lyke a starre, that to reguild his beames

Sucks-in the influence of Phebus streames,

Imbathe's the lynes of his descending light

In the bright fountaines of hir clearest sight.

(lines 155-62)

Making Frances the sun (or a planet, as line 163 figures her) to Tomalin's star puts her into the masculinized role of a desiring sexual subject. Although the Petrarchan cliché of the mistress's eyes like sunbeams does 
suggest feminine possibilities for solar imagery, such is not the case with Frances's fieriness, which is altogether too hot to be anything but masculine: she has "fierce and feruent ... radiance," she darts "fyrie stake's ... at euerie glance," and Cupid likes to play with "euerie atomie / That in hir Sunne-beames swarme aboundantlie" (lines 169, 170, 175-76). ${ }^{10}$ Considering Nashe's lusty Frances as a parodic version of Sidney's chaste Stella would have been hilarious to a reader like the poem's dedicatee, Lord Strange, whose Catholic leanings and political aspirations made the Leicester and Sidney faction inimical to him. ${ }^{11}$

In 1592, when Nashe penned his poem, the scandal of the Earl of Essex's secret marriage to Frances Walsingham Sidney, which the Queen learned of in 1590, was farther in the past than the Leicester discovery was when Spenser published The Shepheardes Calender. However, Nashe may have aimed, not at referring to old news, but at providing a satirical back-story for the newest news: the Queen's punishment of Sir Walter Raleigh and Elizabeth Throckmorton for marrying without her permission. If Nashe wrote the poem after March, when the birth of Damerei Raleigh ended the secret part of the Raleigh secret marriage, then he would seem to be using the allusions to two other famous scandals of royal favorites marrying ladies-in-waiting to the Queen without her permission to make a larger point about the Queen. Lettice Knollys, ladyin-waiting to the Queen, drew the Queen's ire by marrying her favorite, the Earl of Leicester. Frances Walsingham Sidney, lady-in-waiting to the Queen, infuriated the Queen by marrying her favorite, the Earl of Essex. Elizabeth Throckmorton, lady-in-waiting to the Queen, won a trip to the Tower for marrying the Queen's favorite, Sir Walter Raleigh. Nashe brings all three of these scandals into play in his poem-writing in 1592, when the Raleigh scandal was fresh; alluding to "March," which names Lettice and thus makes reference to the Leicester scandal; and naming Frances to call to mind the Essex marriage scandal. When we read with all three stories in mind, Elizabeth becomes the brothel-keeper, the "foggie threechinnd dame, / That us'd to take yong wenches for to tame" (lines 29-30), and the brothel in the city where the valentine Frances takes refuge becomes the court. This view of Elizabeth aligns her firmly with Venus, not Diana, as Tomalin indicates by invoking the aid of Venus ("venus be

10 Moulton (Before Pornography, 181-82) provides a more detailed discussion of the connection between humours theory and Frances's heat to argue for Frances as masculinized to an early modern audience.

11 See Nicholl (Cup of News, 189-96) for details regarding Lord Strange's connections with Catholicism and Catholic plots to bring him to the throne. 
my speede," line 43) while being led by the madam to the place "Where venus bounzing vestalls skirmish oft" (line 48).

If I am correct, it is no wonder that Nashe made no efforts to publish the poem, but its transmission to the present through six distinct manuscripts, in addition to the fact that his enemy Gabriel Harvey knew enough of the poem to have an opinion about it, suggests something of the pleasure that many of his contemporaries took in the poem, pleasure heightened, I argue, by Nashe's transformation of the innocent hunting boys of Bion, Ronsard, and Spenser into the disappointed Tomalin, whose hopeful ideas about love are shattered by Frances's insatiable desire, and the dildo she uses to quench it.

\section{Satirizing the quean: Venus as Elizabeth in Spenser's Muiopotmos and Dymoke's Caltha Poetarum}

In the previous section, I suggested the possibility that Thomas Nashe's madam, associated with Venus, may have glanced at Queen Elizabeth and her famous jealousy of courtier-favorites who fell for (and married) ladies-in-waiting. In this section and the "coda" that follows, I continue to explore the satirical potential for mocking the Virgin Queen, Elizabeth, by associating her-more or less circuitously-with Venus. I will look at two poems, Spenser's Muiopotmos; or, The Fate of the Butterflie, which, though part of the recalled Complaints volume, has never been perceived as the target of the censorship, and Tailboys Dymoke's Caltha Poetarum, a nearly forgotten poem whose chief claim to fame is having been named in the Bishops' Ban of 1599.

If the easy and obvious way to compliment Elizabeth is to celebrate her chastity and compare her to Diana, then Venus becomes the easy and obvious route to satire, and we find this occurring in both Muiopotmos and Caltha Poetarum in their plot points of a jealous Venus seeking revenge on beautiful maidens. ${ }^{12}$ I do not aim to argue strenuously that Spenser intended to satirize the Queen with his brief interpolated tale of Venus and Astery, because the matter must rest in the realm of speculation, though a few critics have noted in passing the possibility of a correspondence between the Venus of Muiopotmos and Queen Elizabeth (see, e.g., Lemmi, "Allegorical meaning," 740-41; Harris, "Butterfly," 305; Herron, "Plucking," 100). Rather, I wish to read these two poems side by side not only to prove that at least one contemporary reader, Tailboys Dymoke,

12 For discussion of contemporary critiques of Elizabeth that hinged on supposed inchastity, see Levin, Heart and Stomach, 66-90. 
did believe that Spenser intended his Venus to refer to the Queen, but also to consider Spenser's role as satirical inspiration for Dymoke's poem, which alludes insistently to Muiopotmos while pushing the indirect allegorical satire of the Queen much, much farther than Spenser's does.

The cold trail on Caltha Poetarum went cold again after Leslie Hotson's 1938 article identifying Tailboys Dymoke as the author of the poem, which in 1599 was published under the name "Thomas Cutwode," banned by the bishops, and then reprieved from being burned. Although being named in the Bishops' Ban rescued the poem from complete oblivion in the succeeding centuries, the poem has nevertheless languished in critical obscurity for two reasons: (1) Tailboys Dymoke died at some point before February 1603 and thus did not follow up this poem with a more substantial body of work (Larkum, "Dymoke"); (2) the poem is obviously allegorical, and it is more difficult to create allegorical interpretations of a work written by an unknown author. Still, even after 1938, when Caltha's author ceased to be an unknown author, he remained lacking in fame, and critics are simply less interested in deciphering the allegories of un-famous authors. For example, Arthur Henry Bullen, in an early Dictionary of National Biography (DNB) entry on "Thomas Cutwode," published before Hotson discovered Cutwode's identity, for example, dismisses the poem as follows: "The poem shows some skill of versification and archness of fancy; but as the veiled personal allusions are now unintelligible, it is tedious to read through the 187 stanzas" ("Thomas Cutwode," 370). Hotson attempts to make the poem less "tedious" by identifying some of the allegorical figures and places, but, because he fails to notice the pervasive Catholic imagery, he misses the mark repeatedly, for example in reading Diana as representing Queen Elizabeth and Ephesus as London (Hotson, "Marigold," 61). Thus, Hotson's conclusions as a whole are weakened by some of his overconfident assertions regarding what are in fact highly speculative identifications.

Hotson's early twentieth-century preference for assertiveness in identifying topical allusions appears in his contemporaries' innumerable attempts to unravel the allegory of Spenser's Muiopotmos, giving the lie to Bullen's suggestion in the DNB that incomprehensible allegories are therefore inherently tedious. Summing up more than a century of Muiopotmos criticism in 1970, Franklin Court writes: "For at least the past one hundred thirty-four years, it has been subjected to so many various interpretations that even a cursory study of the scholarship written about it gets tedious and discomforting" (Court, "Theme and structure," 1). A small selection of examples from the period of the "Old Historicism" will 
suffice to convey a sense of the variety of interpretations of this apparently incomprehensible allegory: early twentieth-century critics argued for interpreting the butterfly Clarion and the spider Aragnoll as Spenser and Lady Carey, Raleigh and Essex, Sidney and Burghley, Sidney and the Duc d'Alençon, and Essex and Burghley (respectively, Long, "Spenser's"; Lyons, "Spenser's"; Hulbert, "New interpretation"; Lemmi, "Allegorical meaning"; Harris, "Butterfly"). Muiopotmos criticism eventually moved on to other concerns, but this scattershot approach to allegorical interpretation proves that incomprehensible does not necessarily mean uninteresting, if the author is famous enough.

It is not my aim here to provide identifications for every little flower and bee in Caltha Poetarum; however, while granting that the allegory is extremely obscure, I think there is much more to say about this poem than has yet been said, and I believe that considering its intertextuality with Muiopotmos can help us to make sense of this poem as a satire, rather than just labeling it "obscene" and moving on, as the poem's few critics have tended to do. John Peter cites three page numbers (without quoting or describing the events, which include descriptions of the Bee sucking honey from Caltha, the nondescription of the metamorphosed Caltha's genitalia, and Musaeus's sexual encounter with Venus) that render this a "wanton work" (Peter, Complaint, 149), though he sees it as sufficiently mild that he speculates that the bishops, upon examining the work, may have reprieved it because they found it not obscene enough to merit the flames. The focus on obscenity fits with his overall thesis about the Bishops' Ban: "That it was very largely with obscenity that they were concerned there can surely be no doubt whatever" (Peter, Complaint, 150).

Richard McCabe, with an opposing thesis, that the target of the ban "was neither eroticism nor lewdness but satire itself", quickly dispenses with the one work in which he finds no satire by referring to the "one undoubtedly obscene work, Thomas Cutwode's Caltha Poetarum" before moving on to more comprehensible satires included in the ban (McCabe, "Elizabethan satire," 189). Cyndia Susan Clegg does find satire in the "primarily erotic" poem, but not satirical intention (Press Censorship Elizabethan, 213). Her overall argument posits offensiveness to the Earl of Essex as the connection among all of the works named in the ban. Although she cannot find any pointed satire on Essex in Caltha, she notes that a contemporary manuscript poem connected Essex with bee imagery-she mentions "The bussin Bee's Complaint" but could have included another possibly Essex-authored poem, "It was a time when silly Bees could speak." To the extent, then, that Essex was associated with 
bee imagery in the popular imagination, Caltha Poetarum may have been read as satirizing the Earl, leading to its scrutiny by the bishops (Clegg, Press Censorship Elizabethan, 214).

Overall-and this comes as no surprise, given that practically no one reads this poem-the critical enterprise regarding Caltha has been characterized by insufficient care since the time of Hotson. Clegg does not cite Hotson and thus does not engage with his argument when she creates her own allegorical interpretation. Hannah Betts does cite Hotson in passing, but her brief treatment of the poem focuses only on the erotic blazon of Caltha and its debts to Spenser's less explicitly erotic blazon of Belphoebe in Faerie Queene, Book 2, canto 3. She notes Hotson's identifications of the bee with Dymoke himself and Caltha as a lady-in-waiting, closing with one of Hotson's incorrect identifications: "Diana, unsurprisingly, represents the queen" (Betts, "The image," 173). William R. Jones, in a confusing passage that cites Betts apparently erroneously, repeats Clegg's identification of the bee with Essex without citing Clegg before arriving at an identification of Venus with the Queen that he does not own but that does not come from either Clegg or the source cited immediately thereafter, that is, Betts p. 173 (Jones, "Bishops' Ban," 337).

In short, no one has engaged in a serious and sustained way with the allegory of Caltha Poetarum since Hotson, and Hotson's eagerness to make positive identifications too often impeded his critical acumen. I will argue a number of interrelated theses here: (1) Dymoke reads the Venus-Astery episode in Spenser's Muiopotmos as satirizing Queen Elizabeth's notorious jealousy. (2) He helps his readers to understand his own satire by calling their attention to his poem's intertextuality with Muiopotmos through multiple plot and thematic parallels, suggesting that other contemporary readers also read Spenser's Venus as a satire on the Queen. (3) He departs-radically—from his Spenserian prototype to create a Catholic-themed satire that is quite shocking in its allegorical animus against the Queen.

Given the obscurity of the poem, a plot summary is in order. The poem opens in a garden in the North; Hotson's success in identifying the poem's personal satire, which was animated by the contentious relationship that Tailboys Dymoke and his brother Sir Edward Dymoke, the Queen's Champion, had with their uncle, Henry, Second Earl of Lincoln, aids in recognizing the setting as Lincoln. And yet this garden in Lincoln bears striking resemblance in some respects to Queen Elizabeth's court in London: Venus rules over this garden in which the plants and flowers play at love, but she gets very angry when the inhabitants of the garden do 
not play at love as she wishes them to. She becomes angry with the Marigold, Caltha, for two reasons: Caltha is "the Viccar of a vaine vsurping Queene" (Dymoke, Caltha, 32.4) ${ }^{13}$ - that is, Diana-and she does not return the love of the woodbine. Venus persuades Cupid to shoot Caltha, but at the last moment, the Bee accidentally gets in the way and is shot. Overwhelmed by love, he starts a new, idolatrous religion, Calthanism (a parody of Petrarchanism using Catholic imagery), and persuades his hive to become coreligionists with him. Venus, like Elizabeth angered by love that she has not sanctioned and outraged as well by this heretical religious sect, goes to war against the bees using spiders as her foot-soldiers. The Bee becomes trapped in a spiderweb, which makes it possible for Venus and Cupid to take him prisoner. The Bee stings Cupid and then escapes.

Meanwhile, Diana comes to Caltha to rescue her from the wrath of Venus. She metamorphoses Caltha into a human and takes her away from the garden. Venus has succeeded in destroying the Bee's hive, and so the Bee dresses as a pilgrim and sets off alone, still practicing Calthanism and "Blessing his Marygold with Aue-maries" (116.5). He ends up in Ephesus (i.e., Rome), and, once there, his worship immediately shifts from Calthanism to Roman Catholic worship practices. He makes his way to the garden where Diana and Caltha are; because of the Bee's excitement at seeing her, Caltha is able to recognize him as the Bee who saved her from Cupid's arrow. To reward him, Diana transforms him into a man and-wonder of wonders! - gives him a penis, because, having lost his sting to Cupid, he metamorphoses without genitals. She also grants him a wish; apparently cured entirely of Calthanism, he asks not for love but for the gift of music. Diana grants the wish and renames him Musaeus. In human form, Musaeus heads back to the garden in the North to take revenge on Venus. Venus asks Musaeus to watch over her while she sleeps, to protect her from her enemy the Bee. He agrees and plays the fiddle until she falls asleep:

And downe he lies, and leanes vpon her hips,

And licorously he kist the Ladies lips.

Now whether that this Lady slept or no, or winked wild, as little wantons vse:

There will I leaue you, for I do not know, iudge of it as you list, for you may chuse: And me I pray you heartily excuse.

13 Quotations from the poem will be cited parenthetically in the text by stanza and line number. 
But there the fidler found an instrument,

That makes him mirth \& much mad meriment.

There is certainly sufficient erotic material in the poem to explain Caltha's inclusion in the works named in the Bishops' Ban-although we are talking of bees and flowers, the poem is definitely sexier than the also-banned Pigmalions Image, by John Marston. However, representing Queen Elizabeth as Venus and then having her raped-or faux-somnolently seduced-by a vagrant musician within the context of a barely concealed pro-Catholic agenda creates offense of an entirely different order.

Dymoke offers readers two signposts for interpreting the poem's allegory: the cue to search for Catholic meanings suggests the author's general stance on political and religious issues, and indications to read with Spenser's Muiopotmos in mind lead the reader to understand Venus as allegorically representing Elizabeth, which is, I believe, the key to understanding the poem as a whole. Dymoke alerts the reader to be attentive to Catholic readings in the second stanza, in which he invokes the goddess Flora to be his Muse and to bring him flowers "For to attend my Virgin Mary-gold" (2.6). This is the first of many examples of Catholic concepts and imagery. Early in the poem, Dymoke creates a smokescreen for his pro-Catholic stance by using Catholic imagery to convey a negative judgment in the idolatrous Calthanist worship practices, similar to Spenser's use of Roman Catholic props to indicate to readers of The Faerie Queene that Archimago does not merit trust. Later, however, in Ephesus/ Rome, Dymoke presents Catholic liturgical and worship practices as unambiguously positive. Although we have nothing other than the poem on which to base an assessment of Dymoke's personal religious affiliation, his parents were Catholic recusants, lending support to internal evidence that the author of Caltha Poetarum endorsed Catholicism. The Catholic Encyclopedia names Sir Robert Dymoke (d. 1580) a "confessor of the faith"; notes his associations with the Catholic priests Richard Kirkman, William Lacy, and Edmund Campion (including retaining Kirkman in 1579 as a tutor for his sons, perhaps including Tailboys, who was eighteen years old at the time); and details his death in prison for recusancy ("Dymoke"; Camm, "Robert Dymoke”; Wainwright, "Bl. William Lacy"; Rabenstein, "Kirkman").

Reading the poem with the author's probable Catholicism in mind leads one to make different allegorical interpretations than one might otherwise make. That a Catholic would use a poem by the staunch Prot- 
estant Spenser to sharpen and focus his satire may seem surprising, but it suggests how influential Spenser was as an allegorical satirist in the 1590s. ${ }^{14}$ Dymoke creates numerous parallels between his poem and Spenser's Muiopotmos to highlight the importance of the earlier poem as an intertext. Both are Ovidian poems of metamorphosis, in which "two mightie ones" (Spenser, Muiopotmos, line 3) interact or interfere with the lives of mortals, including in each poem two metamorphoses. In Muiopotmos, although there has been a great deal of debate regarding the identity of the two mighty ones, Don Cameron Allen's influential interpretation of the allegory as referring to the progress of the soul has led to general acceptance of his identification of them as Venus and Minerva (Allen, "On Spenser's"). In Caltha, on the other hand, the two mighty ones are Venus and Diana. The metamorphoses in Muiopotmos occur because of envy-either Venus's envy of Astery leading to her transformation of the girl to a butterfly or Arachne's envy of Minerva as cause of her own metamorphosis into a spider (Bond, "Invidia")—and lead to a diminution or debasement of a human. In contrast to this trajectory in Muiopotmos, Dymoke creates his stories of metamorphosis to highlight the Catholic concept of grace as exemplified in Diana, representing the Virgin Mary, and the transformations she effects move in the opposite direction from Muiopotmos: from flower and bee to human. In Caltha, unlike Muiopotmos, Venus has no supernatural powers: she needs help from the woodbine to heal her son Cupid from the Bee's sting, for example, and so metamorphosing those who offend her is out of the question. Diana, on the other hand, grants metamorphosis as a boon: she changes Caltha into a human to protect her from Venus, and she makes the Bee human to reward him for saving Caltha from Venus.

We also find numerous plot parallels connecting the two insect protagonists, Muiopotmos's butterfly Clarion and Caltha Poetarum's unnamed Bee. Where Clarion has a mock-epic arming before setting out into the garden (lines 56-91), the Bee's hivemates help him with his epic disarming when he returns from the garden after being shot by Cupid and falling in love with Caltha (stanzas 63-64); here, as with the knights of The Faerie Queene, "the disarming of the hero is ... a metaphor for a yielding of the self to lust" (Moulton, Before Pornography, 177). The Bee

14 Numerous scholars have explored the significance of Protestant thought to Muiopotmos; for example, see Weiner ("Spenser's Muiopotmos") for an analysis of the poem as illustrating Protestant skepticism of allegory; Brown ("The allegory") for an argument that Spenser explores eschatological questions through the poem; and Anderson ("Spenser's Muiopotmos," 119-23) for a discussion of the impact of Calvinist and Reformation thought on Muiopotmos. 
disarms immediately after indulging in the lustful pleasure of tasting the flower Caltha (stanzas 60-61), a scene that pushes to clear eroticism the incipient lustfulness that many scholars have noted in Clarion's greedy tasting of flowers. In Muiopotmos, Clarion

casts his glutton sense to satisfie,

Now sucking of the sap of herbe most meete,

Or of the deaw, which yet on them does lie,

Now in the same bathing his tender feete.

(lines 179-82)

Similarly but more explicitly, in Caltha Poetarum the Bee approaches Caltha:

Vpon her flew the flie and suckt her sweet, and plaid full peartly with that pretie one,

And there full featly labourd with his feet, and kist her, least he shuld be deemd a drone:

Now blest be loue, for there was loue alone,

The Bee begins to find and stir his sting,

Beleeue me (loue) thou art a wanton thing.

(stanza 60)

In the next stanza, with his sting apparently fully stirred, "in her circle vp and downe he hops" (61.3). The final plot parallel-the entrapment of the hero in a spiderweb (Muiopotmos lines 417-40, Caltha Poetarum stanzas 75-79) - is of course the final event in Clarion's life. However, through the grace of Diana, the Bee goes on to have a much more rewarding, and quite literally more human, life after escaping from Venus's henchmen, the spiders, and leaving the garden.

In addition to the mythological framework and the plot parallels between the two insect heroes, Dymoke also models his poem generically on Spenser's, with several genre markers to encourage his reader to interpret this as a mock-epic. Although twentieth-century critics engaged in considerable debate over generic classification for Muiopotmos, Dymoke appears to be one early modern reader for whom the mock-epic elements had priority. Thomas Nadal in 1910 argued that Muiopotmos was mockheroic as a way of arguing against it being allegorical; he compared it with Chaucer's Sir Thopas and the Nun's Priest's Tale, a source-text that Judith Anderson has also explored (Nadal, "Spenser's"; Anderson, "Spenser's Muiopotmos"). Isabel Rathborne continued this dichotomization of allegory versus mock-epic by calling the poem an unfinished mock-epic and comparing it to the pseudo-Homer's Batrachomyomachia and Heywood's 
The Spider and the Flie (Rathborne, "Another interpretation"). From the 1970s, there has been scholarly consensus that Muiopotmos is a mockepic, but without the assumption that this genre is incompatible with allegorical meanings (e.g., Dundas, "Muiopotmos," 33; Brinkley, "Spenser's Muiopotmos," 668; Rustici, "Muiopotmos," 165; Wilson-Okamura, Virgil, 196). Dymoke creates generic parallels with Muiopotmos, parallels that reinforce an interpretation of both poems as mock-epics, by including an invocation (Dymoke invokes Flora, appropriate for a tale with a happy ending set in a garden), by treating an insect as an epic hero, and by treating something quite natural (i.e., a spider catches a butterfly or bee) with language appropriate for an epic battle.

Without the parallels with Muiopotmos, there is surely enough to get this poem censored - the erotic language alone might have been enough. The poem may also have offended by using language of crookedness and crippling, which by 1599 was strongly associated with satires on Robert Cecil, whose hunchback offered satirists a ready target for mockery (Croft, "Reputation"). After his escape from the spiderweb, the Bee's "legs \& knees as camocks wer all crooked / That vp \& down did carie him with care" (55.2-3). ${ }^{15}$ Later, when Musaeus, the former Bee, prepares to return to the garden, he ties to his back a "bumfiddle," which "sags vpon his shoulders til they crack: / That made the little fidling fellow hutch, / As he had gone his crookback with a crutch" (155.5-7). Because this crookbacked Musaeus will later rape Venus/Elizabeth, interpreting him as Cecil would add extra insult. Whatever the potential for offense created by the poem's frank treatments of sex or the possible mockery of Robert Cecil's disability, we should consider as well the value of reading Muiopotmos as intertextually important to Dymoke's satire, given the care Dymoke took to connect his poem with Spenser's. Doing so, in addition to providing the key to Dymoke's satire on Elizabeth, also helps us to understand how Spenser's contemporaries read Muiopotmos.

One sixteenth-century reader, Sir Thomas Tresham, saw Prosopopoia; or, Mother Hubberds Tale as the cause of the offense that led to the callingin of Spenser's Complaints volume in 1591 (Peterson, "Laurel crown"); the fact that the other poems in the Complaints volume were reprinted in 1611, but that Mother Hubberds Tale was not reprinted until 1612, after Robert Cecil's death, has been taken as corroboration that it was indeed the principal offender in the volume. Certainly, Mother Hubberds

15 Oxford English Dictionary, s.v. "cammock, n. 2": "1. A crooked staff, a crook; esp. a stick or club with a crooked head, used in games to drive a ball, or the like; a hockey-stick; hence, the game played with such a stick." 
Tale presents a clear and detailed satire on William Cecil (and to a lesser extent his son Robert), but the invented myth of Venus and Astery in Muiopotmos can be read as a milder and vaguer criticism of Queen Elizabeth herself. That Dymoke creates so many parallels with Muiopotmos in a poem that creates a harsh and quite damning satire on the Queen suggests that he believed that other sixteenth-century readers also saw in Spenser's Venus a veiled reference to the Queen.

Many recent critics have read Muiopotmos as allegorically representing the Elizabethan court. For example, Robert Brinkley asserts that "the fate of the butterfly offers an appropriate image for one of the fates at Gloriana's court" (Brinkley, "Spenser's Muiopotmos," 668), and Ayesha Ramachandran argues that "By associating the Elizabethan court with the romance garden rather than the epic battlefield, Spenser reveals and redefines the power relations that are at stake: romance is the world of Circe's bed, of Acrasia's garden and Aragnoll's web, a world where the artfulness of women, the duplicity and dissimulation associated with female power, prevails over single-minded epic might" (Ramachandran, "Clarion," 81). With one exception, even the Old Historicists, however, generally hesitated to identify Venus allegorically, despite their often breathless enthusiasm for hypotheses regarding the true identity of Clarion. C.W. Lemmi, as part of his argument that Clarion represents Philip Sidney, created the following chain of associations: "If Asterie stands for Penelope Devereux, how are we to interpret the episode? Colin Clouts Come Home Again would be sufficient to tell us that Stella was of Elizabeth's train of maidens. Venus must therefore stand for the Queen; and the occurrences allegorized in the episode must be connected with the Court" (Lemmi, "Allegorical meaning," 740). Lemmi moves from this identification to an unacceptably inventive string of hypotheses that depend upon it, but his interest lies in the allegory of Sidney, rather than possible satire of the Queen. Other critics took Lemmi to task for his speculations (e.g., Denkinger, "Spenser's Muiopotmos"; and Strathmann, "Allegorical meaning"), with Emma Denkinger directly addressing the Venus/Elizabeth identification (and taking it as axiomatic that Spenser would never satirize Elizabeth): "If Elizabeth is Venus, and Lettice Knolles is Psyche, Leicester automatically becomes Cupid and Elizabeth's son, which seeing they were of even age, is not only impossible but ungallant to boot!" (Denkinger, "Spenser's Muiopotmos," 272). More recently, Elizabeth Mazzola has built upon Lemmi's work to create a more measured and less speculative assessment of the possibility that Spenser used Clarion to refer to Sidney, but she does not deal with Lemmi's Venus/Elizabeth 
hypothesis. ${ }^{16}$ Denkinger's refusal to entertain the hypothesis that Spenser might create an "ungallant" allegory depends, of course, upon the nowdoubted assumption that Spenser harbored no ambivalence toward the Queen (see, e.g., the essays in Walker, Dissing Elizabeth).

Judith Anderson notes the significance of the placement of the VenusAstery episode immediately after the narration of the Court Ladies' envy of Clarion's wings: "The Court Ladies' cupidity, their mean possessiveness, takes form in the myth of Astery, precipitating the very myth that it introduces" (Anderson, "Spenser's Muiopotmos," 117). Anderson suggests that Spenser connects the ladies of the court with the envious nymphs, and this provides a clue to the possible fruitfulness of reading the Astery episode with the Elizabethan court in mind. The tale itself-invented by Spenser ${ }^{17}$ - provides a myth of origin for the beauty of butterflies' wings: Venus's beautiful nymph Astery, by virtue of being "nimbler joynted" and "more industrious" than the other nymphs, gathers more flowers (Spenser, Muiopotmos, lines 121, 122). When Venus praises Astery, the other nymphs, envious, tell her that Cupid offered "secret aide" (line 127). Venus remembers Cupid's secret love for Psyche, becomes enraged, and transforms Astery into a butterfly. I find here no specific details to support an identification with Queen Elizabeth; rather, the situation, in broadest outline, simply feels familiar: a goddess with more power than discretion becomes-not once but twice-infuriated when her male favorite secretly associates with a beautiful woman. For two decades, Elizabeth's male courtiers worked around her famous jealousy by secretly marrying; when the secrets were revealed, husband and wife dealt with the ensuing rage, with the brunt often falling on the wife.

Bolder than Spenser in Muiopotmos, Dymoke provides Caltha Poetarum with multiple "entry codes," in Annabel Patterson's sense of clues that alert a reader to consider the possibility of hidden meanings (Censorship and Interpretation, 57). These include a frank admission in G.S.'s commendatory poem that, though concealed, "Persons of good worth are ment" (A8r); the heavy use of Catholic-associated language and imagery; and the numerous parallels with Muiopotmos, especially the plot element of a jealous Venus who revenges herself on beautiful young women. Dymoke builds upon Spenser's generalized satire of Eliza-

16 Mazzola briefly discusses the episode, arguing that Clarion owes his existence to a "mother's worries about her own reproductive powers" (Mazzola, "Sidney, Spenser," 77).

17 Andrew Weiner summarizes the appearances of characters named Astery elsewhere in myth to confirm the originality of Spenser's story, which is notable "for Venus' jealous over-reaction to the envious lies told about her innocent and devoted votary, whose punishment is totally undeserved" (Weiner, "Spenser's Muiopotmos," 215). 
beth's jealousy to create a focused, harsh attack on Elizabeth that uses satirical allegory to make two points, both related to false religion: (1) as the symbolic enforcer of conformity to the Church of England, Elizabeth engages in injustice to support a damnable heresy; (2) as the idol of Elizabethan Petrarchanism, Elizabeth conflates love, worship, and politics in ways that degrade the right practice of all three. Dymoke makes these points through the allegorical presentation of two distinct false religions: the religion endorsed by Venus for the whole garden (a sort of state religion), and the idolatrous religion of Calthanism, created by the Bee under the influence of Cupid's arrow, which corresponds to Petrarchanism.

In the time before the action of the poem, Venus used marigolds extensively in the practice of her state religion, as Cupid reminds her when urging her to quell her desire for revenge. Cupid's lengthy description of garlands of marigolds for Venus herself, for the birds who drew her chariot, and for the crowds going to her church (stanzas 46-48), includes explicitly religious language:

How often haue the buds bene laid abroad vpon the traces whereas you should tread:

How oft haue they thy stately altars strawd, and we exalting there thy holy head,

Whilst Hymnes wer sung, \& sacred Psalms were sed:

Me thinks I see how all the rabble runs,

Vnto thy Church, with chaines of golden suns.

(Dymoke, Caltha, stanza 48)

This history of including marigolds in the state-sanctioned worship practice helps to explain Venus's fury that the marigold Caltha is now "the Viccar of a vaine vsurping Queene" (i.e., Diana) who "disdain[s] both the heuenly powers" $(32.4,6)$. Venus's efforts to take revenge on Caltha for her religious defection involve pressuring Cupid to shoot her with one of his arrows, and this limited recourse to violence in response to one religious nonconformist becomes all-out war when she learns of the Bee's creation of the rival religion of Calthanism:

The fame of these [i.e., the "Caltheans"], and of this new religion, was spred abroad with passing great report,

And rumor of it, rattles through each Region, till that it came to Lady Venus cort,

God speed my pen for heere begins the sport:

For now doth Venus bite and beate her fists,

To be reuenged on these Calthanists.

(stanza 73) 
She sends spiders to defeat the Calthanist bees (stanzas 75-79); when this does not succeed, she smokes the bees out of their hives (stanzas 112-13).

Venus's insistence on religious conformity would easily remind a Catholic reading audience of Elizabeth's dealings with Catholic recusants, and Dymoke strengthens the sense of Venus as the figurehead of a false religion by contrasting Venus's complete lack of supernatural power with Diana's miraculous powers. Dymoke's Venus lacks not only supernatural power but also even basic knowledge that any early modern mother would have: When the Bee stings Cupid in the face, Venus has no skill to heal him. She goes "vp and downe the Garden ... / to gather all the coolest hearbs that grow: / To phisick and to leach her wounded lad" $(84.1-3,6)$, and yet we quickly learn that she does not know what plants can heal: after "trying many precious plants," she arrives at the woodbine tree and asks him "what phisick ther might bee / To take away the stinging of the flee" (85.4-5). Diana, in contrast, over and over again practices benign and wholly efficacious magic: metamorphosing Caltha into a human (stanzas 92-99), the Bee into the human Musaeus (stanza 139), and the void of Musaeus's genital region into "his priuie knacks" (142.5). At first glance it may seem odd that Dymoke has chosen to describe Diana's magic with language reminiscent of witchcraft. During her metamorphosis of Caltha, Diana

mumbels in her mouth with whisper talk, And there in circle wise about did walk.

As Tragetors for spirits set their spels,

To coniure vp the Fairies or the Elues.

She uses "blessed bookes of diuination" (139.2) to transform the Bee, and in her creation of his penis she seems even more witchlike: "From forth the Hawthorne hedge she plucks a thorne, / and works and makes his picture all of wax," then "she pricks the hawthorn wher his secrets laks," and his genitals appear (142.1-2, 4). Odd as this witchlike language may appear in relation to Diana, who here represents Catholicism or the Virgin Mary, this embodied magic — as opposed to the acts of pure will we associate with gods and goddesses in myth-makes her more similar to the Catholic priest, whose sacramental "magic" involves not mere will but the "mumbling" of words and the use of objects (water, oil, bread, wine) to metamorphose things and people from one spiritual state to another.

18 Oxford English Dictionary, s.v. "tregetour, n.": "One who works magic or plays tricks by sleight of hand; a conjurer; a juggler; hence, a trickster, a deceiver." 
As the instigator of the cupidinous arrow that leads the Bee to become an idolatrous Calthanist, Venus bears responsibility for another false religion. In his treatment of Calthanism, Dymoke satirizes the clichés of Petrarchanism by literalizing them. The Bee literally worships the marigold. His idolatry begins after he has metaphorically made love to her ('in her circle vp and downe he hops," etc., as quoted earlier, stanzas 60-61), at which point he begins to elevate her status: "For now no more he cals her Marygold, / but newes from Lady Caltha is he bringing" (62.3-4). This Petrarchan devotion to the lady begins to take on a religious cast, but the reference to "his Goddesse Lady Caltha" (65.7) still falls short of the development of an actual religion, which occurs when he builds a chapel. The passage is worth quoting at length:

In meane while this same mightie bumble Bee, is framing of a Chappell for his Queene,

With strange and costly Archetectury, the rarest sight that euer yet was seene,

Of waxen worke, was neuer like I weene:

Pillers of hony combes with Piramis,

And strong pilasters of great statelinesse.

And at one end there stands a proper steeple, dawbing his height with hony for his lime: And bels to ring in these same pretie people, when as they take it to be seruice time, To say their praiers, their Mattens \& their prime And when this Chapell ended was and wald, La santa Caltha, this same bee it cald.

With Virgin wax he makes a hony alter, and on it stands, the torches and the tapers,

Where he must sing his Rosarye and Psalter, and pray deuoutly on his holy papers, With book, with candlelight, with bels \& clappers, And in the praise of Goddesse Caltha sing, That all the holy quier \& Church may ring.

(stanzas 68-70)

These stanzas create a strong sense of Catholic worship practices, and shortly afterward, the Bee creates a Catholic-like hierarchy when he "maketh Priests and Presbiters, and some / of Fryers \& Monks he makes a rabble rout, / Of Clarks \& Limitors to kneele and lowt" (72.3-5). Even after Venus destroys his Calthanist community by smoking the beehives, and even after Caltha disappears from the garden (rescued and then 
metamorphosed by Diana, unbeknownst to the Bee), the Bee remains true to his pseudo-faith, dressing himself as a pilgrim and leaving the garden himself. He "meanes to wander vncoth waies" and "seek strange countries far, that be vnknown" (115.4, 7; surely an echo of Chaucer's "to seken straunge strondes / To ferne halwes, kowthe in sondry londes"; General Prologue, lines 13-15).

Dymoke connects Calthanism to Petrarchanism through some typical clichés, such as the blazon of the metamorphosed Caltha (stanzas 95-99). Hannah Betts makes an excellent analysis of connections between this passage and Spenser's blazon of Belphoebe in Faerie Queene (2.3.22-30), but I disagree with her conclusion that, by emphasizing the sexual allure of Caltha, Dymoke "consigns the blazon to the category of writing about prostitutes" (Betts, “The image," 174). Rather, the blazon, by describing Caltha's sexual desirability in terms of both her physicality and religious devotion, connects her body metaphorically to the chapel that the Bee already built for her:

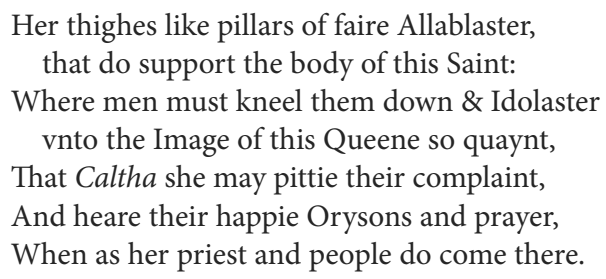

(stanza 99)

The standard Petrarchan blazon thus circles back to Dymoke's literalization of the well-worn metaphor of love as religious devotion. Similarly, Dymoke literalizes the hair-as-net metaphor by having the Bee become actually caught in the metamorphosed Caltha's beautiful hair: "So is this Bee entangled in her locks, / and fetterd in these golden yealow strings" (130.3-4). Through these playful references to Petrarchan clichés, Dymoke clarifies that, although he uses Catholic terminology and imagery to describe Calthanism, his satire targets not Catholicism but the Petrarchan love games of Venus/Elizabeth's court.

Further proof that Catholicism is the solution, not the problem, comes when the Bee is cured of his idolatrous Calthanism immediately upon arriving in Ephesus. Whereas Hotson believes that Ephesus represents London, Dymoke identifies it as Rome by associating it with Diana and by using the plane tree as the symbol of the city. The Bee arrives in Ephesus, "where chaste Diana and her vestals bee," and rests in "Platanus, 
/ an aged and an auncient hollow tree" (121.2, 3-4). ${ }^{19}$ Upon waking the next morning, the Bee performs his "Mattins" and "lauds and Letanies" before moving on to the Psalms, "With Pater Noster, and with Auie Marie" $(122.2,4,7)$. There is no suggestion of Calthanism in this stanza; though the Bee still loves Caltha, as we recognize when he finds her in Diana's garden immediately after this, he no longer loves her idolatrously. Proof of his complete conversion from Calthanism comes when Diana, after metamorphosing him into a man, tells him to make a wish, asking, "What pleasure couldst thou wish to passe thy daies?" (147.5). Surprisingly, his wish has nothing to do with Caltha; instead, he asks Diana to make him into a good musician and thus is transformed into the human Musaeus.

Despite being called in by the authorities, the poems of Spenser's Complaints volume had sufficient presence (either through copies that were not turned in or through manuscript copies; Peterson, "Laurel crown"; Beal, Index, Vol. 1, part 2, 527-28) to influence other satires written in the nearly two decades before the collection was printed again. At least some contemporary readers must have read Spenser's Venus in Muiopotmos as satirizing Queen Elizabeth, because Dymoke makes this identification key to understanding his satire. He takes some pains to obfuscate his targets-using Catholic language to criticize Calthanism, for example, obscures his strongly pro-Catholic message, and the common use of Diana to allegorize Elizabeth makes it less likely that some readers would instead connect Venus to Elizabeth. With these efforts at self-protection from censorship, the intertextual connections with Muiopotmos become essential in comprehending Dymoke's satirical message.

\section{Coda}

I close this chapter not by connecting more dots, but by drawing out threads, spinning an imaginative web that might suggest a connection between Shakespeare's Venus and Adonis (1593) and the poems discussed in this chapter. ${ }^{20}$ We find in Shakespeare's Adonis an iteration of those boys, beginning with Bion's, who would rather hunt than love, and in

19 According to Rembert Dodoens, "The Plane is a strange tree, the whiche in time past hath bene of great estimation in Italie and Rome" (A Nievve Herball, 755). Further, the Catholic writer Richard Verstegan, in a series of odes based on "Epithets of Our Blessed Lady," includes an ode to the Virgin Mary as the plane tree, "Quasi Platanus" (Odes, 48).

20 Patrick Cheney provides a good list of references up through 2004 for scholars who have looked at Shakespeare's debts to Spenser in Venus and Adonis (Cheney, Shakespeare, 88n23); see also Harwood ("Venus"). 
his Venus further development of Muiopotmos's jealous and powerful goddess as possible satire on the Queen. Addressing his poem to the Catholic Earl of Southampton, Shakespeare may satirize the Queen with the same doubts about her chastity that the Catholic author Tailboys Dymoke would express six years later in explicitly creating his Elizabethan Venus as the antitype to the Marian Diana. The argument can only be speculative, based on what Anne Lake Prescott calls "vibes" in her own study of Spenserian influence on Shakespeare, but the vibes suggest interesting and worthwhile interpretations of Shakespeare's fascinating poem (Prescott, "Equinoctial," 169).

In his immaturity and his lack of interest in Venus, Adonis differs significantly from Shakespeare's sources (Dubrow, Captive Victors, 43). We can speculate from their dedications to Henry Wriothesley, Third Earl of Southampton, that Shakespeare and Nashe were acquainted during this period, suggesting the possibility that Shakespeare was aware of Nashe's parodic adaptation of Spenser's young hunter Thomalin. ${ }^{21}$ In the ephebe Adonis we can imagine, almost grown up, the hunting boy that I traced from Bion through Ronsard and Spenser to Nashe. Shakespeare's Adonis expresses as his own the antipathetic views on love taught to the boy by the more experienced adults to whom he turns for help:

"I know not love," quoth he, "nor will not know it,

Unless it be a boar, and then I chase it.

'Tis much to borrow, and I will not owe it, My love to love is love but to disgrace it;

For I have heard it is a life in death,

That laughs and weeps, and all but with a breath."

(Venus and Adonis, lines 409-14)

If Shakespeare sought to satirize the absurd courtship games between the aging Queen and her reluctant but obliged political "suitors," the character type of the boy who would rather hunt than love provides an admirable allegorization of the male participant in the games. Patrick Cheney notes the opposition of values between Venus and Adonis, with Adonis espousing goals and perspectives that make of him a "Virgilian figure of pastoral and epic ... voicing an aesthetics that resembles Spenser's" (Cheney, Shakespeare, 91). But whereas Cheney sees in Venus's character the exemplification of "Marlowe's Ovidian aesthetics" (Cheney, Shakespeare, 91) - and Cheney creates a persuasive case for reading Venus's

21 Shakespeare dedicated Venus and Adonis to the Earl in 1593 and The Rape of Lucrece in 1594; Nashe dedicated The Unfortunate Traveler to him in 1594. See Nicholl, Cup of News, 160-62, for discussion of the possible acquaintanceship. 
rhetoric as Marlovian-I speculate that the idea to use Venus to satirize the Queen came from Shakespeare's reading of Muiopotmos.

At least one sixteenth-century reader did interpret Shakespeare's Venus as allegorizing Queen Elizabeth. Leslie Hotson, who discovered the identity of Tailboys Dymoke and learned most of what we know about his life and writings, also found in his archival work a letter by William Reynolds describing Shakespeare's poem as "a nother booke made of Venus and Adonis wherin a queene represents the person of Venus." He continues at some length to describe the plot of the poem, including his observation that there is "much ado $\mathrm{w}^{\text {th }}$ red \& whyte" and highlighting the references to Venus as a "phery nimpfe" (qtd. in Hotson, Shakespeare's, 143). Unfortunately, we cannot take Reynolds as a typical Elizabethan reader: Hotson describes him as suffering from "persecution mania," and Katherine Duncan-Jones expands upon the biographical information supplied by Hotson, emphasizing Reynolds's outrage at his treatment as a former soldier, his religious enthusiasm, and his tenacity in sharing his opinions with the Queen and her counselors (which led to numerous stays in prison) to come to a tentative post hoc diagnosis of paranoid schizophrenia (Hotson, Shakespeare's 142; Duncan-Jones, "Much ado," 480-86).

Modern critics have been more circumspect than Reynolds in considering the possibility that Elizabethan sexual politics inform Shakespeare's characterization of Venus. Heather Dubrow, for instance, suggests that "Venus' assertions of power may well reflect resentment of Elizabeth herself... . Hence in this epyllion ... ambivalence about an unsuccessfully manipulative heroine encodes ambivalence about a brilliantly manipulative queen" (Dubrow, Captive Victors, 34); and Judith Anderson refers somewhat coyly to "those critics who suspect that Shakespeare's poem might have a satirical relation to courtship, especially under a Queen who affected a Petrarchan role" (Anderson, "Venus and Adonis," 211). In other words, actual readings of Venus and Adonis as satire are difficult, perhaps impossible, to make, but many readers have the impression that satiric "vibes" exist in the work. I am equally unable to make an actual argument that Shakespeare read Muiopotmos, although A. Kent Hieatt has argued that Shakespeare did read the Complaints volume of 1591, demonstrating Shakespearean allusions to Spenser's Ruines of Rome: by Bellay and suggesting possible familiarity with Mother Hubberds Tale (Hieatt, "The genesis"). Still, for me, Shakespeare's lusty, large, and somewhat ridiculous Venus calls unavoidably to mind Spenser's jealous and petulant Venus in Muiopotmos, as well as Dymoke's more obviously Elizabeth-targeting Venus, who combines the worst qualities of both. 
Critics have found Spenserian echoes in Shakespeare's image of Venus leaning over Adonis, clasping him in her arms while "glutton-like she feeds, yet never filleth" (line 548), with Judith Anderson paying the most careful attention to the repetition of this image in Books 2 and 3 of Spenser's Faerie Queene; she analyzes the posture's significance when it appears in Acrasia, Cymoent, Belphoebe, Venus, Argante, and Britomart in order to comment on its significance to Venus and Adonis (Anderson, "Venus and Adonis," 209-11). Elsewhere, Anderson provides a fascinating argument for Argante as the lustful antitype to the chaste Belphoebe; that is, in addition to the "most royall Queene or Empresse" figured by Gloriana and the "most vertuous and beautifull Lady" allegorized in Belphoebe (Faerie Queene, 716), the many other mirrors of Elizabeth include Argante as a parodic double. Anderson's evidence for the connection comes from Layamon's use of the name Argante for the elf queen on whose island Arthur recovers from an injury. Anderson concedes that a reader would be unlikely to make the connection between Argante and the Faerie Queene without recourse to Layamon's Brut (Anderson, "Arthur," 130). We might find, though, in the similarity that Prescott notes between "a sweating goddess in pursuit of a reluctant ephebe" and "Spenser's lustful giantess Argante chasing down young squires" (Prescott, "Equinoctial," 170) a suggestion that Shakespeare made the connection.

This tangled web connecting Adonis to Spenser's and Nashe's Tomalins and their predecessors and Muiopotmos's Venus to Elizabeth, Faerie Queene's Argante to Elizabeth, and both to Shakespeare's Venus may seem too speculative-one of the unavoidable hazards of considering indirect satire of Elizabethan England. My purpose, though, is not to create an argument about one-to-one correspondences and identifications, à la the Old Historicist accounts of Muiopotmos and Caltha Poetarum cited in this chapter, but to consider the dynamics of the subsystem of satire in the 1590s and the role of Spenser as inspiration for authors like Thomas Nashe and Tailboys Dymoke, who, though dissimilar to Spenser in political and religious outlook, found it worthwhile to use his works to help them in conveying their own meanings. In the next chapter, I will look at Thomas Middleton in 1599 and 1604 as a young writer who appreciated Spenser not only poetically but also politically, and thus used allusions to Spenser to convey his own affiliation with the ideas about government and religions associated with the more famous poet. 